\title{
Research Progress on $\mathrm{N}_{2} \mathrm{O}$ Emissions from Soil in Facility Vegetable Plot
}

\author{
Weihan Wang \\ Zhejiang Water Conservancy and Hydropower College, Hangzhou, China \\ Email: 54620633@qq.com
}

How to cite this paper: Wang, W. H. (2018). Research Progress on $\mathrm{N}_{2} \mathrm{O}$ Emissions from Soil in Facility Vegetable Plot. Journal of Geoscience and Environment Protection, 6, 171-175. https://doi.org/10.4236/gep.2018.612014

Received: November 20, 2018

Accepted: December 24, 2018

Published: December 27, 2018

Copyright $\odot 2018$ by author and Scientific Research Publishing Inc. This work is licensed under the Creative Commons Attribution International License (CC BY 4.0).

http://creativecommons.org/licenses/by/4.0/

\begin{abstract}
$\mathrm{N}_{2} \mathrm{O}$ is one of the important greenhouse gases that cause global warming. $\mathrm{N}_{2} \mathrm{O}$ emissions from the soil of the facility vegetable land are an important source. It is important to summarize the research on the $\mathrm{N}_{2} \mathrm{O}$ emissions from the soil in the facility vegetable land, and is also of great significance to study on the emission mechanism of $\mathrm{N}_{2} \mathrm{O}$ in China's agricultural fields. This paper summarizes the development status of the facility vegetable plot in China, tracks the progress of soil $\mathrm{N}_{2} \mathrm{O}$ emission research in the facility vegetable plot, and makes a prospect of the research in this field.
\end{abstract}

\section{Keywords}

Facility Vegetable Plot, $\mathrm{N}_{2} \mathrm{O}$, Emissions

\section{Introduction}

Global warming is becoming a common challenge for mankind. In 2007, the IPCC released a scientific assessment of climate. It pointed out that policymakers in various countries must act quickly to fight climate change. As the largest developing country, China's economy is developing rapidly, and its total greenhouse gas emissions are increasing year by year, under increasing pressure from the international community (IPCC, 2007).

$\mathrm{N}_{2} \mathrm{O}$ is one of the most important greenhouse gases that cause climate warming. It can continuously absorb long-wave infrared radiation from sunlight, block the thermal radiation from the surface to outer space, destroy the ozone layer, and increase the temperature in the atmosphere, bringing about a greenhouse effect. The contribution of $\mathrm{N}_{2} \mathrm{O}$ to global warming is about $5 \%$, but the content of $\mathrm{N}_{2} \mathrm{O}$ in the atmosphere is increasing at a rate of about $0.2 \%$ to $0.3 \%$, and the warming effect caused by it is about 300 times that of $\mathrm{CO}_{2}$. Therefore, 
the research on $\mathrm{N}_{2} \mathrm{O}$ has always been concerned by scholars (Li, 2016).

Agricultural production is a very important source of $\mathrm{N}_{2} \mathrm{O}$ emissions, accounting for about 58 per cent of all anthropogenic sources of $\mathrm{N}_{2} \mathrm{O}$ (IPCC, 2007). In recent years, with the improvement of the living standards of the Chinese people, the area of vegetable cultivation in facilities has been rapidly improved. The special greenhouse conditions of vegetable soil in facilities, coupled with the large amount of fertilization, may increase $\mathrm{N}_{2} \mathrm{O}$ emissions. Therefore, it is of great practical significance to summarize the results of the research on soil $\mathrm{N}_{2} \mathrm{O}$ emissions from the facility vegetable plots for the sustainable development of agricultural production and global environmental improvement in China.

\section{Current Status of Vegetable Development in Facilities}

Facilities vegetable cultivation refers to the mode of changing the local climate environment through certain facilities and carrying out anti-season and protected vegetable cultivation. Facilities and vegetable cultivation can avoid the harm caused by extreme temperatures and strong light to vegetable production. It belongs to high-input, high-output, and labor-intensive industries. The methods of cultivation of facilities include film cover, plastic sheds, and smart greenhouses.

In recent years, the production of vegetables in facilities in China has developed rapidly. The area of vegetable cultivation in facilities has grown from 1.83 million hectare in 2000 to 39.15 million hectare in 2016, an average annual increase of more than 0.13 million hectare, and the output of vegetable facilities has reached 252 million tons, accounting for $30.5 \%$ of the total vegetable output. The net output value of the vegetable industry in facilities in China has reached more than 570 billion yuan. It has become the world's largest producer and consumer of vegetables (Li, 2016).

At present, China's facilities and vegetables industry is mainly in the Huanghuaihai region and the Bohai Rim region in North China, accounting for about $60 \%$ of the country's total planting area, followed by the middle and lower reaches of the Yangtze River and the Northwest region, accounting for about $20 \%$ and $7 \%$. Looking at the provinces, they are mainly concentrated in Shandong, Liaoning, Hebei, Jiangsu, and Zhejiang provinces. In terms of the variety of vegetables in facilities, there are mainly peppers, tomatoes, cucumbers, eggplants and other vegetables. Among them, the cultivated area of tomato facilities is 0.78 million hectare, accounting for $57.2 \%$ of the total area of tomatoes. It is the first place in the cultivated and sown area of facilities in China (Journal of Agricultural Resources and Markets, 2018).

\subsection{Irrigation Mode of Facilities Vegetable}

Irrigation mode has a very important effect on the production of plant vegetables, and it will also have a certain impact on the soil environment. At present, the irrigation methods of our country's facilities are mainly ditch irrigation, local 
irrigation(including micro-spraying, drip irrigation, inrush irrigation, membrane irrigation, membrane irrigation, etc.) (Jiang, 2017), and ceramic tube negative pressure irrigation. The research of many scholars shows that the water use efficiency of local irrigation facilities is greatly improved, and the effect of increasing production is obvious (Huo, Niu, \& Wang, 2012).

\subsection{Soil Fertilization in Facilities}

Fertilization is one of the main factors affecting the safe production of vegetable plots in facilities. The unreasonable application of fertilizer will not only reduce the yield and quality of vegetables, but also lead to soil pollution and environmental damage. According to statistics, in 2014, the amount of vegetable fertilizer per hectare was 25.05 times that of the three major food crops, and the amount of input was nearly twice that of the three major food crops. Vegetables, especially facilities, generally use more than 2 to 4 times the amount of fertilizer they require, and in some areas even reach more than 10 times the actual demand. The supply and demand ratio is seriously out of balance, and the utilization rate of vegetable crop nitrogen fertilizer is generally less than $10 \%$ in the season compared with field crops. The utilization rate of nitrogen fertilizer in Ota crops is $30 \%$ to $35 \%$, phosphorus fertilizer is $10 \%$ to $25 \%$, and potassium fertilizer is $40 \%$ to $50 \%$ (Wang, 2016). Excessive fertilization will lead to a series of environmental problems, such as greenhouse gas emissions.

\subsection{Study on $\mathrm{N}_{2} \mathrm{O}$ Emission from Soil in Facilities Vegetable Land}

With the promotion of high-efficiency water-saving irrigation technology, soil water and heat conditions and microbial environment in the facility vegetable field ecosystem may aggravate the emission of greenhouse gas $\left(\mathrm{N}_{2} \mathrm{O}\right)$, and the ecological environment of the farmland brought about by this problem can not be ignored. Drip irrigation technology is implemented with a small amount of precision irrigation, and the soil moisture and fertilization methods of farmland are very different. The resulting changes in soil temperature and humidity, soil $\mathrm{pH}$, microbiological activity, and nitrogen content in the soil will greatly interfere with the nitrification and denitrification of $\mathrm{N}_{2} \mathrm{O}$, thus affecting the emission of $\mathrm{N}_{2} \mathrm{O}$ from the soil to the atmosphere.

Wang Fangmin and others (Wang et al., 2012) summarized the emission laws of soil $\mathrm{N}_{2} \mathrm{O}$ under different irrigation methods. Wang Weihan and others (Wang et al., 2014) studied the emission laws of soil $\mathrm{N}_{2} \mathrm{O}$ in green pepper soil under drip irrigation, and pointed out that the emission flux of $\mathrm{N}_{2} \mathrm{O}$ in green pepper soil under drip irrigation gradually increased with the extension of the reproductive period of green pepper soil.

Studies have shown that about $20 \%$ of Chinese farmland $\mathrm{N}_{2} \mathrm{O}$ emissions come from vegetable cultivation (Zheng et al., 2004), characterized by high energy consumption, high emissions and high pollution (Wang, 2015). Facilities and vegetable plots are generally characterized by high energy consumption, high 
emissions and high pollution. Studies have shown that the soil $\mathrm{N}_{2} \mathrm{O}$ emission flux is lower than that of normal application and higher than that of non-nitrogen treatment (Yang et al., 2013).

The emission flux of $\mathrm{N}_{2} \mathrm{O}$ is higher than that of border irrigation under drip irrigation conditions, but it is less volatile than that of border irrigation. It is believed that drip irrigation promotes $\mathrm{N}_{2} \mathrm{O}$ emissions in green pepper land. Under the current management measures, reasonable reduction of organic fertilizer and fertilizer nitrogen application is an effective way to reduce $\mathrm{N}_{2} \mathrm{O}$ emissions in vegetable farms (Xu et al., 2016).

The lower soil pore water content under drip irrigation conditions causes nitrification in the soil to be higher than denitrification, and its $\mathrm{NH}^{4+}-\mathrm{N}$ and $\mathrm{NO}_{3}-\mathrm{N}$ are higher than diffuse irrigation, which can inhibit denitrification and reduce $\mathrm{N}_{2} \mathrm{O}$ emissions (Abalos et al., 2014). Aguilera et al. (2013) believe that there is a strong denitrification of soil in the wet area near the drip head, which reduces $\mathrm{N}_{2} \mathrm{O}$ emissions. Kennedy's studies have also shown that drip fertilization increases tomato yields, promotes the uptake and use of water fertilizer, reduces residual nitrogen content in the soil, and thus reduces $\mathrm{N}_{2} \mathrm{O}$ emissions (Kennedy, Emma, \& Johan, 2013). At present, there is still no conclusion on the effect of drip irrigation on the soil $\mathrm{N}_{2} \mathrm{O}$ emissions in the facility vegetable land.

\section{Conclusion and Perspective}

$\mathrm{N}_{2} \mathrm{O}$ is one of the most important greenhouse gases that cause climate warming, and the facility vegetable land is an important source of $\mathrm{N}_{2} \mathrm{O}$ emissions from farmland soil. This paper summarizes the development status of the facility vegetable plot and tracks the research progress of $\mathrm{N}_{2} \mathrm{O}$ emissions from the facility vegetable plot. Control of fertilizer application, particularly organic and nitrogen fertilizer, can significantly reduce $\mathrm{N}_{2} \mathrm{O}$ emissions from facility plots under the agricultural production conditions of existing facilities. At present, there is less research on plant vegetables with a considerable proportion of crops sown in China, the only research focused on the regulation of $\mathrm{N}_{2} \mathrm{O}$ emissions from plant plots in conventional fertilizer and water management, and there is a lack of systematic and in-depth mechanical research. In particular, the water effects of soil $\mathrm{N}_{2} \mathrm{O}$ emissions are studied. The relationship between plant growth and development and soil water, temperature and nutrient transformation in plant and $\mathrm{N}_{2} \mathrm{O}$ emissions in high-efficiency and water-saving irrigation has yet to be studied systematically.

\section{Acknowledgements}

This research was supported by Zhejiang Provincial Natural Science Foundation of China under Grant No. LY15E090005.

\section{Conflicts of Interest}

The author declares no conflicts of interest regarding the publication of this paper. 


\section{References}

Abalos, D., Sanchez-Martin, L., Garcia-Torres, L., van Groenigen, J. W., \& Vallejo, A. (2014). Management of Irrigation Frequency and Nitrogen Fertilization to Mitigate GHG and NO Emissions from Drip-Fertigated Crops. Science of the Total Environment, 4, 880-888. https://doi.org/10.1016/j.scitotenv.2014.05.065

Aguilera, E., Lassaletta, L., Sanz-Cobena, A., Garnier, J., \& Vallejo, A. (2013). The Potential of Organic Fertilizers and Water Management to Reduce $\mathrm{N}_{2} \mathrm{O}$ Emissions in Mediterranean Climate Cropping Systems. Agriculture, Ecosystems and Environment, 164, $32-52$.

Huo, H. X., Niu, W. Q., \& Wang, Y. K. (2012). Research Progress and Outlook on Vegetable Irrigation Technology in Facilities. Water-Saving Irrigation, 4, 22-25.

IPCC (2007). Climate Change 2007: Mitigation. Contribution of Working Group III to the Fourth Assessment Report of the Intergovernmental Panel on Climate Change. Cambridge: Cambridge University Press.

Jiang, Y. Q. (2017). Effects of Drip Irrigation and Fertilization on Soil $\mathrm{N}_{2} \mathrm{O}$ and NO Emissions from Plant Plots and Their Contribution to agricultural Resources and Area-Based Research Institutes. Beijing: Chinese Academy of Agricultural Sciences.

Journal of Agricultural Resources and Markets (2018). 3.93 Million Hectare, See Where the Main Distribution of Vegetables Facilities in China.

http://www.sohu.com/a/219359539_658625

Kennedy, L. T., Emma, C. S., \& Johan, S. (2013). Reduced Nitrous Oxide Emissions and Increased Yields in California Tomato Cropping Systems under Drip Irrigation and Fertigation. Agriculture, Ecosystems and Environment, 170, 16-27.

https://doi.org/10.1016/j.agee.2013.02.002

Li, T. L. (2016). Current Situation and Trend of Vegetable Technology and Industrial Development in China. China Rural Science and Technology, 5, 75-77.

Wang, F. M., Wang, W. H., Wang, H., \& Mao, Q. (2012). Progress in Research on the Impact of Irrigation Methods on No Emissions from Farming. Anhui Agricultural Science, 36, 17595-17597.

Wang, J. J. (2016). Investigation and Study of Vegetable Fertilization in China. China Agricular Technology Extension, 32, 11-13.

Wang, W. H., Mao, Q., \& Yan, A. L. (2014). Study on the Emission Regulation of $\mathrm{N}_{2} \mathrm{O}$ in Qingjiao Di under Drip Irrigation. China Rural Water Conservancy and Hydropower, 7, 31-34.

Wang, Y. L. (2015). Study on Soil $\mathrm{N}_{2} \mathrm{O}$ Emission under the Integration of Vegetable Soil Fertilizer in Beijing Suburbs. Beijing: Chinese Academy of Agricultural Sciences.

Xu, Y., Liu, Z. H., Wei, J. L., \& Shi, Y. (2016). North Typical Facility Vegetable Soil $\mathrm{N}_{2} \mathrm{O}$ Emission Characteristics. Shandong Agricultural Science, 48, 86-91.

Yang, Y., Sun, Q. P., Li, J. J. et al. (2013). Effects of Different Water Fertilizer Treatment on $\mathrm{N}_{2} \mathrm{O}$ Emissions from Facilities. Journal of Plant Nutrition and Fertilizer, 19, 430-436.

Zheng, X. H., Han, S. H., Huang, Y., Wang, Y. S., \& Wang, M. X. (2004). Re-Quantifying the Emission Factors Based on Field Measurements and Estimating the Direct $\mathrm{N}_{2} \mathrm{O}$ Emission from Chinese Croplands. Global Biogeochemical Cycles, 18, 1-19. https://doi.org/10.1029/2003GB002167 